INTERNATIONAL JOURNAL OF MULTIDISCIPLINARY RESEARCH AND ANALYSis

ISSN[Online] : 2643-9875 || ISSN[Print] : 2643-9840

Volume 03 Issue 11 November 2020

DOI: 10.47191/ijmra/v3-i11-03, Impact Factor : 5.522

Page No : $211-217$

\title{
Evaluation of the Liquidity of Pharmaceutical Firms Listed in the Hanoi Stock Exchange
}

\author{
Nguyen Van $\mathrm{Hau}^{1}$, Tran Thi Thu Thuy ${ }^{2}, \mathrm{Vu}$ Thi The ${ }^{3}$ \\ ${ }^{1}$ Finance and Accounting 1 Department, Posts and Telecommunications Institute of Technology, Vietnam \\ ${ }^{2,3}$ Faculty of Accounting, University of Labor and Social Affairs, Vietnam
}

\begin{abstract}
This paper investigates the liquidity of pharmaceutical firms Listed in the Hanoi Stock Exchange (HNX) by using table data for the period 2015-2019. Four observedvariables were formulated including: (i) Cash Ratio (CR), (ii) Quick Ratio (QR), Current Ratio (CCR) and Interest Coverage Ratio (ICR). The findings conclude that have significantly different in the liquidity of pharmaceutical firms Listed in the HNX, in the long and shortrun. The implication of our results shows that the liquidity of pharmaceutical firms were interested by objects, including business administrators, creditor and other objects to have the necessary rationale for making a decision.
\end{abstract}

KEYWORDS: iquidity, pharmaceutical firms, financial ratios.

JEL CLASSIFICATION: M40, F65, E42

\section{INTRODUCTION}

The enterprises' liquidity reflects the financial relationship between the ability of enterprises to pay short - term obligations and the payables in the period (Luu and $\mathrm{Vu}, 2010$ ). Liquidity is the financial capacity of that company to meet the debt payment needs for individuals and organizations that have a loan or debt relationship with the enterprise.

Ensuring liquidity of a company contributes to helping enterprises maintain and strengthen their operating system to continue investing and developing to make profit in the future. On the other hand, when understanding the solvency situation, managers will have a more accurate orientation for their capital investment, reducing unfortunate risks.

The pharmaceutical industry has achieved remarkable achievements. Through many years of construction and development, the pharmaceutical sector is gradually meeting copious essential products for the economy, serving domestic consumption, substituting import products and engaging in exporting with a variety in designs and types. Several products have had high competitiveness in the domestic and international markets.

The solvency of pharmaceutical firms listed in the Hanoi Stock Exchange in recent years has many different points. It is necessary to evaluate the solvency of each company to provide information for business managers, creditors and related parties to make decisions.

\section{LITERATURE REVIEW}

Based on the Greek food industry database, Lyroudi\&Lazaridis (2000) studied the relationship between liquidity and profitability and debt ratio. In which, the liquidity includes: Cash ratio (CR), Quick ratio (QR) and Current ratio. Yucel\& Kurt (2002) analyzed data of 167 listed companies on the Turkish stock market over the period of 1995-2000. The research results clearly showed that the loan structure has a negative correlation with liquidity, including Cash ratio (CR) and Quick ratio (QR). Janbaz (2010) uses CR to represent the liquidity when studying the relationship between solvency and capital structure and profitability of 70 listed companies on the Iranian stock exchange during 2006- 2007.

In Vietnam, Nguyen (2014) used the dependent variable: solvency which is represented as liquidity when studying the solvency of listed firms in Hanoi Stock Exchange. When researching the relationship of capital structure with the liquidity of the group of non-financial enterprises in Vietnam, Le (2015) stated that liquidity includes: (i) the ability to pay short-term principals, measured by the current ratio, and (ii) the ability to pay interest costs, measured by interest coverage ratio. The solvency of the 


\section{Evaluation of the Liquidity of Pharmaceutical Firms Listed in the Hanoi Stock Exchange}

enterprise according to Nguyen (2017) includes: cash ratio, quick ratio, short-term debt payment ratio (current ratio) and longterm liabilities solvency.

Inheriting results of previous studies, this study evaluated and measured the solvency of pharmaceutical firms listed in HNX in 4 criteria as follows.

\begin{tabular}{|l|l|l|}
\hline Code & Scale & Sources \\
\hline S1 & Cash Ratio (CR) & Lyroudi\&Lazaridis (2000), Yucel\& Kurt (2002), Janbaz (2010), Nguyen (2017) \\
\hline S2 & Quick Ratio (QR) & Lyroudi\&Lazaridis (2000), Yucel\& Kurt (2002), Nguyen (2017) \\
\hline S3 & Current Ratio (CCR) & Lyroudi\&Lazaridis (2000), Le (2015), Nguyen(2017) \\
\hline S4 & Interest Coverage Ratio (ICR) & Le (2015) \\
\hline
\end{tabular}

\section{METHODOLOGY}

\subsection{Data Definition and Source}

The study employs panel data between 2015 - 2019 for 10 pharmaceutical firms Listed in the Hanoi Stock Exchange. These firms were selected due to data availability. The data was collected from https://financevietstock.vn/. We collected data on indicators that reflected the liquidity of enterprises, such as, CR, QR, CCR andICR. Data was imputed in Excel solfware to analyse.

\subsection{Analysis}

With 4 indicators reflecting liquidity in 5 years; we collected 200 observations. Then we evaluate and analyze. We used tools to evaluate andanalyse the liquidity of pharmaceutical firms, including: Comparison, statistics, synthesis of results.

\section{RESEARCH RESULTSAND DISCUSSION:}

The liquidity of pharmaceutical firms listed in the HNX is shown by 4 indicators IR, QR, CCR and ICR.

Table 1 shows the liquidity when considering each pharmaceutical enterprise in each year, besides the enterprises with good liquidity, there are still certain limited liquidity enterprises (see table 1).

Table 1: The liquidity of pharmaceutical firms listed in the HNX during the period 2015-2019.

\begin{tabular}{|l|l|l|l|l|l|}
\hline Stock code & Year & CR & QR & CCR & ICR \\
\hline AMV & 2015 & 0.33 & 1.74 & 2.48 & 0.30 \\
\hline AMV & 2016 & 0.64 & 2.68 & 2.99 & 1.91 \\
\hline AMV & 2017 & 0.02 & 12.79 & 13.33 & 41.51 \\
\hline AMV & 2018 & 1.41 & 5.22 & 5.36 & 96.23 \\
\hline AMV & 2019 & 0.29 & 3.70 & 4.14 & 125.33 \\
\hline CPC & 2015 & 0.78 & 1.73 & 2.60 & 12.86 \\
\hline CPC & 2016 & 0.84 & 1.65 & 2.42 & 17.58 \\
\hline CPC & 2017 & 0.52 & 1.04 & 2.02 & 9.67 \\
\hline CPC & 2018 & 0.33 & 0.80 & 1.91 & 7.03 \\
\hline CPC & 2019 & 0.56 & 1.67 & 2.38 & 6.01 \\
\hline DBT & 2015 & 0.13 & 0.50 & 1.06 & 4.22 \\
\hline DBT & 2016 & 0.11 & 0.55 & 1.03 & 4.11 \\
\hline DBT & 2017 & 0.19 & 0.73 & 1.23 & 4.12 \\
\hline DBT & 2018 & 0.12 & 0.72 & 1.18 & 2.97 \\
\hline DBT & 2019 & 0.07 & 0.54 & 1.17 & 3.05 \\
\hline DHT & 2015 & 0.07 & 0.58 & 1.41 & 7.34 \\
\hline DHT & 2016 & 0.15 & 0.55 & 1.47 & 8.97 \\
\hline DHT & 2017 & 0.20 & 0.51 & 1.52 & 10.05 \\
\hline DHT & 2018 & 0.13 & 0.55 & 1.58 & 9.23 \\
\hline DHT & 2019 & 0.13 & 0.69 & 1.51 & 8.68 \\
\hline DNM & 2015 & 0.50 & 1.36 & 1.65 & 13.69 \\
\hline DNM & 2016 & 0.15 & 1.35 & 1.69 & 12.94 \\
\hline
\end{tabular}


Evaluation of the Liquidity of Pharmaceutical Firms Listed in the Hanoi Stock Exchange

\begin{tabular}{|c|c|c|c|c|c|}
\hline DNM & 2017 & 0.21 & 1.34 & 1.77 & 8.25 \\
\hline DNM & 2018 & 0.15 & 1.08 & 1.63 & 2.81 \\
\hline DNM & 2019 & 0.24 & 1.04 & 1.35 & 3.34 \\
\hline DP3 & 2015 & 0.14 & 0.43 & 1.36 & 6.36 \\
\hline DP3 & 2016 & 0.33 & 0.89 & 1.86 & 11.31 \\
\hline DP3 & 2017 & 0.50 & 0.97 & 2.05 & 27.79 \\
\hline DP3 & 2018 & 0.79 & 1.52 & 2.58 & 77.92 \\
\hline DP3 & 2019 & 0.81 & 2.76 & 3.59 & 89.89 \\
\hline LDP & 2015 & 0.01 & 0.46 & 1.12 & 13.99 \\
\hline LDP & 2016 & 0.04 & 0.37 & 1.14 & 9.12 \\
\hline LDP & 2017 & 0.07 & 0.43 & 1.23 & 4.75 \\
\hline LDP & 2018 & 0.06 & 0.36 & 1.04 & 3.25 \\
\hline LDP & 2019 & 0.16 & 0.48 & 1.02 & 3.00 \\
\hline MKV & 2015 & 0.03 & 0.69 & 0.97 & 1.41 \\
\hline MKV & 2016 & 0.12 & 0.65 & 1.05 & 1.82 \\
\hline MKV & 2017 & 0.05 & 0.60 & 0.89 & 1.07 \\
\hline MKV & 2018 & 0.02 & 0.64 & 0.94 & 1.06 \\
\hline MKV & 2019 & 0.05 & 0.73 & 1.13 & 1.63 \\
\hline PMC & 2015 & 2.22 & 2.99 & 4.02 & $(19.12)$ \\
\hline PMC & 2016 & 1.81 & 3.00 & 4.26 & 0.0 \\
\hline PMC & 2017 & 1.50 & 2.94 & 4.35 & 0.0 \\
\hline PMC & 2018 & 3.13 & 3.93 & 5.57 & 0.0 \\
\hline PMC & 2019 & 3.26 & 4.53 & 6.32 & 0.0 \\
\hline PPP & 2015 & 0.26 & 0.71 & 1.12 & 7.49 \\
\hline PPP & 2016 & 0.28 & 0.67 & 1.09 & 92.54 \\
\hline PPP & 2017 & 0.12 & 0.48 & 0.89 & 3.40 \\
\hline PPP & 2018 & 0.29 & 0.59 & 1.33 & 2.91 \\
\hline PPP & 2019 & 0.25 & 0.70 & 1.65 & 7.78 \\
\hline
\end{tabular}

Sources: $\underline{\text { https://finance.vietstock.vn/; and authors synthesized }}$

\section{Cash Ratio (CR)}

CR is synthesized and analyzed in detail in Table 2 and Table 3 as follows:

Table 2: Average CR over the years of pharmaceutical firms listed in the HNX

\begin{tabular}{|l|l|l|l|l|l|l|}
\hline Description & $\mathbf{2 0 1 5}$ & $\mathbf{2 0 1 6}$ & $\mathbf{2 0 1 7}$ & $\mathbf{2 0 1 8}$ & $\mathbf{2 0 1 9}$ & Average 2015-2019 \\
\hline CR (times) & 0.45 & 0.45 & 0.34 & 0.64 & 0.58 & 0.49 \\
\hline
\end{tabular}

Sources: https://finance.vietstock.vn/; and authors synthesized

Table3: Average CR for the period2015-2019 of each pharmaceutical enterprise listed in the HNX

\begin{tabular}{|l|l|l|l|l|}
\hline \multirow{2}{*}{ No } & \multicolumn{2}{|l|}{ CR<0.5 } & $\mathbf{0 . 5 < = C R ~}$ \\
\cline { 2 - 5 } & Stock code & CR & Stock code & CR \\
\hline 1 & MKV & 0.05 & DP3 & 0.51 \\
\hline 2 & LDP & 0.07 & AMV & 0.54 \\
\hline 3 & DBT & 0.12 & CPC & 0.61 \\
\hline 4 & DHT & 0.14 & PMC & 2.38 \\
\hline 5 & PPP & 0.24 & & \\
\hline 6 & DNM & 0.25 & \multicolumn{2}{|}{} \\
\hline
\end{tabular}

Sources: https://finance.vietstock.vn/; and authors synthesized

Cash ratio $=($ Cash + Cash equivalent $) /$ Current liabilities 


\section{Evaluation of the Liquidity of Pharmaceutical Firms Listed in the Hanoi Stock Exchange}

Cash ratio is a measure of a company's liquidity; in particular, it is the ratio of the company's total cash and cash equivalents over its current liabilities.

The cash ratio indicates how much capital an enterprise has in cash to be willing to pay for its short-term debts. Cash ratio is often surveyed by analysts to analyze the solvency of a enterprise (TuyetNhi, 2019a).

Experts say that CR calculates a company's ability to pay short-term debt by cash and cash equilvalent, such as a company's marketable securities. This information is useful to creditors when they decide how much is available to lend to a firm.

Experts also say that the generally accepted cash ratio is approximately 0.5 . The higher the rate is, the more reliable the liquidity of the enterprise is, and vice versa the lower the rate is, the harder it is to trust the liquidity of an enterprise.

Table 2 shows that, the average CR of pharmaceutical firms listed in the HNX over years is 0.49 . In general, pharmaceutical firms have quite stable payment ability in cash. However, considering each enterprise, the result in Table 3 show that 4 firms with stock codes PMC, CPC, AMV, and DP3 have quite high CR, greater than 0.5; which proves that these 4 firms have good cash ratio. The remaining firms still has limited ability to pay debt in cash. Enterprises with stock code MKV, LDP had the lowest CR in the industry.

\section{Quick Ratio (QR)}

QRis synthesized and analyzed in detail in Table 4 and Table 5 as follows:

Table4: Average QR over the years of pharmaceutical firms listed in the HNX

\begin{tabular}{|l|l|l|l|l|l|l|}
\hline Description & $\mathbf{2 0 1 5}$ & $\mathbf{2 0 1 6}$ & $\mathbf{2 0 1 7}$ & $\mathbf{2 0 1 8}$ & $\mathbf{2 0 1 9}$ & Average 2015-2019 \\
\hline QR (times) & 1.12 & 1.24 & 2.18 & 1.54 & 1.68 & 1.55 \\
\hline
\end{tabular}

Sources: https://finance.vietstock.vn/; and authors synthesized

Table5: Average QR for the period2015-2019 of each pharmaceutical enterprise listed in the HNX

\begin{tabular}{|l|l|l|l|l|}
\hline \multirow{2}{*}{ No } & \multicolumn{2}{|l|}{ QR<1.0 } & \multicolumn{1}{l|}{$\mathbf{1 . 0}=<\mathbf{Q R}$} \\
\cline { 2 - 5 } & Stock code & CR & Stock code & CR \\
\hline 1 & LDP & 0.42 & DNM & 1.23 \\
\hline 2 & DHT & 0.58 & DP3 & 1.31 \\
\hline 3 & DBT & 0.61 & CPC & 1.38 \\
\hline 4 & PPP & 0.63 & PMC & 3.48 \\
\hline 5 & MKV & 0.66 & AMV & 5.23 \\
\hline
\end{tabular}

Sources: https://finance.vietstock.vn/; and authors synthesized

Quick Ratio Formula = Quick Assets / Current Liabilities

Quick ratio is used as a measure to assess the ability to immediately pay short-term liabilities by converting short-term assets into cash without having to sell inventories.

Quick Ratio is a much stricter one than the current ratio because it excludes inventory from the calculation formula. This formula is widely used by investors and shows the short-term financial health of a enterprise.

Experts believe that the higher this ratio is, the higher the debt liquidity and vice versa. If this rate is equal to 1 or greater, the ability to respond immediately to short-term debts of a company is high. Enterprises do not encounter difficulties if they need to pay off short-term debts immediately. In contrast, if the quick ratio is less than 1 , the enterprise will not be able to pay all shortterm debts immediately; in other words, the enterprise will face many difficulties if they need to pay off their short - term debts immediately. In further analysis, if the quick ratio is much smaller than the current ratio, it can tell that short-term assets depend heavily on inventories. In this case, the liquidity of the short-term assets is relatively low. Of course, with a ratio of less than 1 , the company may not achieve a good financial position, but that does not mean the company will go bankrupt because there are many ways to raise more capital for debt repayment. In another aspect, if this rate is too high, the capital in cash is too much, which means the working capital turnover is low and the capital use might not efficient. However, the magnitude of this ratio depends on the type of business and the maturity of debts in the period.

Table 4 shows that the average QR of the pharmaceutical firms listed in the HNX over years is 1.55. In general, pharmaceutical firms have fairly stable quick liquidity. However, considering each seperate enterprise, the result in Table 5 show that there are 5 enterprises with QR greater than 1.0. These 5 enterprises have the QR smaller than 1.0. The enterprises with stock codes AMV, PMC have the largest QR. These two enterprises have the highest debt payment ability among 10 pharmaceutical firms listed in 


\section{Evaluation of the Liquidity of Pharmaceutical Firms Listed in the Hanoi Stock Exchange}

HNX. Two enterprises with the securities code LDP, DHT have the lowest QR in the industry. Their debt liquidity is low; therefore, these two enterprises need to take more measures to improve QR.

Current Ratio (CCR)

CCR is synthesized and analyzed in detail in Table 6 and Table 7 as follows:

Table6: Average CCR over the years of pharmaceutical firms listed in the HNX

\begin{tabular}{|l|l|l|l|l|l|l|}
\hline Description & $\mathbf{2 0 1 5}$ & $\mathbf{2 0 1 6}$ & $\mathbf{2 0 1 7}$ & $\mathbf{2 0 1 8}$ & $\mathbf{2 0 1 9}$ & Average 2015-2019 \\
\hline CCR (times) & 1.78 & 1.90 & 2.93 & 2.31 & 2.43 & 2.27 \\
\hline
\end{tabular}

Sources: https://finance.vietstock.vn/; and authors synthesized

Table7: Average CCR for the period2015-2019 of each pharmaceutical enterprise listed in the HNX

\begin{tabular}{|l|l|l|l|l|}
\hline \multirow{2}{*}{ No } & \multicolumn{2}{|l|}{ CCR<1.0 } & $\mathbf{1 . 0}=<$ CCR \\
& Stock code & CR & Stock code & CR \\
\hline 1 & & & MKV & 1.00 \\
\hline 2 & & & LDP & 1.11 \\
\hline 3 & & & DBT & 1.13 \\
\hline 4 & & & PPP & 1.22 \\
\hline 5 & & & DHT & 1.50 \\
\hline 6 & & & DNM & 1.62 \\
\hline 7 & & & CPC & 2.27 \\
\hline 8 & & & DP3 & 2.29 \\
\hline 9 & & & PMC & 4.90 \\
\hline 10 & & & AMV & 5.66 \\
\hline
\end{tabular}

Sources: https://finance.vietstock.vn/; and authors synthesized

Current ratio $=$ Current assets $/$ Current liabilities

This ratio measures the ability of the firm to pay short-term obligations. Current Ratio shows that for each dong of short-term debt that the business is holding, how much short-term asset the enterprise has to pay.

According to financial - accounting experts: If Current Ratio is greater than 1, the enterprise has enough short-term assets to pay off their short-term debts. Conversely, if Current Ratio is less than 1, it means that the enterprise does not have enough shortterm assets to be able to pay off the upcoming debts. In addition, the higher the current ratio is, the more likely a company is to pay off its short-term obligations. However, when this ratio is too high, it may indicate that the company is not using its shortterm assets effectively, or is not managing its working capital well.

When assessing the liquidity situation of an enterprise, analysts often compare the liquidity ratio of an enterprise with the average liquidity ratio of the entire industry in which that enterprise participates.

Table 6 shows that the average Current Ratio of the pharmaceutical firms listed in the HNX over years is 2.27> 1, Overall, pharmaceutical firms listed in the HNX have enough short-term assets to pay off their short-term debts.

Table 7 shows that for each pharmaceutical firm listed in the HNX; all of which (10 enterprises) have CCR> 1.0; all these 10 enterprises have enough short-term assets to pay off short-term debts. However, enterprises with stock codes AMV, PMC have the largest CCR among 10 firms. These two enterprises have greater ability to pay short-term liabilities than the rest do. Two enterprises with stock code MKV, LDP have the smallest CCR among 10 enterprises; therefore, these 2 enterprises need to have specific measures to improve their current liquidity.

Interest coverage ratio (ICR)

ICR is synthesized and analyzed in detail in Table 8 and Table 9 as follows:

Table 8: Average ICR over the years of pharmaceutical firms listed in the HNX

\begin{tabular}{|l|l|l|l|l|l|l|}
\hline Description & $\mathbf{2 0 1 5}$ & $\mathbf{2 0 1 6}$ & $\mathbf{2 0 1 7}$ & $\mathbf{2 0 1 8}$ & $\mathbf{2 0 1 9}$ & Average 2015-2019 \\
\hline ICR (times) & 4.85 & 16.03 & 11.06 & 19.69 & 24.87 & 15.3 \\
\hline
\end{tabular}

Sources: https://finance.vietstock.vn/; and authors synthesized 
Evaluation of the Liquidity of Pharmaceutical Firms Listed in the Hanoi Stock Exchange

Table9: Average ICR for the period2015-2019 of each pharmaceutical enterprise listed in the HNX

\begin{tabular}{|l|l|l|l|l|}
\hline \multirow{2}{*}{ No } & \multicolumn{2}{|l|}{ ICR<2.0 } & $\mathbf{2 . 0}=<$ ICR \\
\cline { 2 - 5 } & Stock code & CR & Stock code & CR \\
\hline 1 & PMC & -3.82 & DBT & 3.69 \\
\hline 2 & MKV & 1.40 & LDP & 5.52 \\
\hline 3 & & & DNM & 8.21 \\
\hline 4 & & & DHT & 8.85 \\
\hline 5 & & & CPC & 10.63 \\
\hline 6 & & & PPP & 22.82 \\
\hline 7 & & & DP3 & 42.65 \\
\hline 8 & & & AMV & 53.06 \\
\hline
\end{tabular}

Sources: https://finance.vietstock.vn/; and authors synthesized

Interest coverage ratio = Earnings before interest and taxes/Interest expense

Interest coverage ratio shows the ability to guarantee repayment of loan interests of the enterprise. At the same time, this financial indicator also shows financial ability that the enterprise creates to cover the cost of borrowing capital for production and business. Interest coverage ratio is the debt ratio and the rate of return used to determine the possibility that an enterprise can pay interest on its outstanding debt (TuyetNhi, 2019b).

According to financial experts, the larger the interest coverage ratio is, usually greater than 2, the more positive the firm's ability to pay interest and is. In contrast, the lower this rate is, the lower liquidity that corporate maintains to make loan interest payments.

Table 8 shows: The average ICR of the pharmaceutical firms listed in the HNX over years is quite high. Therefore, pharmaceutical firms have sufficient ability to pay interest on loans.

Table 9 shows the ICR of each separate pharmaceutical firm listed in the HNX: The firms with stock codes PMC, MKV have the lowest ICR of 10, with the rate less than 2, proving that these 2 enterprises are still not good at paying interests. Meanwhile, 8 out of 10 pharmaceutical enterprises listed in the HNX have an average ICR of greater than 2 for years, so these 8 enterprises are capable of paying interest on loans positively. The ability to pay interest of firms with securities codes AMV, DP3 are highest compared to other firms. At the same time, through the information on cash flow reports, it can be confirmed that the results of production and business activities of these two firms also generate good cash flows. Therefore, this proves a fairly positive ability to pay interest on loans in these 2 enterprises.

\section{CONCLUSION:}

The liquidity ratios provide analysts with the solvency and liquidity of the enterprise at a point of time. At the same time, when considering the liquidity ratios, the analyst is aware of the past and possible trends of enterprise payment ability.

Enterprises with low quick ratio may lead to the risk that enterprises cannot guarantee money for payment. Therefore, these enterprises need to improve their capital in cash to meet the payment needs.

Current ratio at any time is just a snapshot, so it does not accurately reflect the liquidity or solvency of the enterprise. To remedy this, the quick ratio is applied.

Interest coverage rates are often surveyed by analysts to analyze the solvency of an enterprise (TuyetNhi, 2019b).

\section{REFERENCES}

1) Janbaz, M. (2010). Capital structure decisions in the Iranian corporate sector. International Research Journal of Finance and Economics, 8, 24-34.

2) Le, H. V. (2015). Capital structure and liquidity of Vietnamese companies. Banking Science and Training Review, 157, 66-71. [Vietnamese]

3) Luu, T. H., \& Vu, D. H. (2011). Business Finance textbook. National Economics University Pushlisher. [Vietnamese]

4) Lyroudi, K., \&Lazaridis, O. (2000). The Cash Conversion Cycle and Liquidity Analysis of the Food Industry in Greece. Social Science Research Network Electronic Paper Collection. NetDOI:10.2139/SSRN.236175.

5) Nguyen, D, T. (2014).Factors of affecting the liquidity of listed firms in Vietnam.Science research topic.[Vietnamese]

6) Nguyen, V. C. (2017). Business analysis textbook. . National Economics University Pushlisher. [Vietnamese] 


\section{Evaluation of the Liquidity of Pharmaceutical Firms Listed in the Hanoi Stock Exchange}

7) TuyetNhi (2019a). Whatis Cash Ratio?Formula for calculation.Retrieved October 10, 2019 from https://vietnambiz.vn/[Vietnamese]

8) TuyetNhi (2019b). What is Interest coverage ratio? Formula for calculation. Retrieved October 10, 2019 from https://vietnambiz.vn/[Vietnamese]

9) Web:https://tinnhanhchungkhoan.vn/he-so-thanh-toan-nhanh-post67355.html; https://financevietstock.vn.[Vietnamese]

10) Yucel, T. and Kurt, G. (2002). Cash Conversion Cycle. Cash Management and Profitability: an Empirical Study on the ISE Traded Companies, the ISE Review, 6 (22), 3-15. 